\title{
CHLORODISCUS NATANS PETER. \& HANS. (CHLOROPHYCEAE) FROM A MESOTROPHIC PEAT BOG IN LOWER SILESIA (SOUTH-WESTERN POLAND)
}

\author{
JAN MATUŁA \\ Department of Botany and Plant Ecology, University of Agriculture \\ Cybulskiego 32, 50-205 Wrocław, Poland \\ e-mail:matula@ozi.ar.wroc.pl
}

(Received: June 3, 2004. Accepted: July 20, 2004)

\begin{abstract}
The paper concerns a very rare and poorly known species of green alga Chlorodiscus natans Petersen \& Hansen, discovered in the peat bog "Brzeźnik" near Bolesławiec (Poland). This is the second stand so far discovered in the world. The collected material allowed complementing the knowledge on organization of colonies, morphology and way of hair development. The remaining features, particularly the structure of the cell, are in concordance with the hitherto diagnosis of that species. The paper presents problems connected with the taxonomic affiliation of the species and describes the ecological conditions of habitats occupied by this alga.
\end{abstract}

KEY WORDS: Chlorodiscus natans, Chlorophyceae, taxonomy, peat bog.

\section{INTRODUCTION}

The green alga was discovered by Petersen and Hansen (1960) in neuston of small water hollows on peat bogs in Jutland (Denmark).

The described in the present paper stand of Chlorodiscus natans Peter. \& Hans. was found for the first time in 1990 in the peat bog "Brzeźnik" near Bolesławiec (Lower Silesia, South-Western Poland). This alga develops to this day, though irregularly. This is so far the second known in the world site of occurrence of this green alga. The peat bog is a nature reserve, because of the well preserved and rare in that area communities of Erica tetralix L. The layer developed on an easy slope under the influence of water flowing from sources and flows situated in the higher localized forest. The hydrological conditions and the vegetation covering the site indicate the mesotrophic character of the peat bog. The whole peat bog is overgrown by thin distributed, low trees of Pinus sylvestris L., Betula pubescens Ehrh. and Frangula alnus Mill. shrubs. In the herb layer there occur in great numbers Erica tetralix, Sphagnum fallax (Klinggr.) Klinggr., S. flexuosum Dozy and Molk., S. subsecundum Ness ex Sturn., S. papillosum Lindb., Eriophorum vaginatum L., E. angustifolium Honck, Oxycoccus quadripetalus Gilb., Vaccinium myrtillus L., Molinia coerulea (L.) Moenhl., Juncus conglomerates L., J. effusus L., Calamagrostis villosa (Chaix) Geml., Carex canescens L., C. fusca (L.) Alt., C. rostrata Stokes, Phragmites communis Trin.
The green alga Chlorodiscus natans has been found among mucilaginous or filamentous algae free floating in water or settled in the bottom of the ditch cutting through the peat bog. The ditch-water, $30 \mathrm{~cm}$ deep, drips slowly among S. fallax, S. subsecundum, C. fusca, C. canescens, Agrostis canina L., Juncus articulatus L., J. effusus.

The water-acidity values in the growing season ranged from 5.8-6.47. Petersen and Hansen (1960) used to find this alga in somewhat more acid waters, at $\mathrm{pH}$ 5.1-5.3. The electrolytic conductivity of water in the "Brzeźnik" peat bog was on the average $258 \mu \mathrm{S} \times \mathrm{cm}^{-1}$. The content of nu-

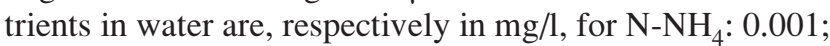
$\mathrm{N}-\mathrm{NO}_{3}: 5.8 ; \mathrm{P}^{-\mathrm{PO}_{4}}$ : 0.001; Ca: 24.0; Mg: 5.7; K: 2.7; Na: 13.6. More detailed floristic and ecological data of the peat bog are given in Matuła (1995).

\section{OBSERVATIONS}

Chlorodiscus natans in the peat bog "Brzeźnik" occurred sporadically. During observations carried out in the years 1990-1999 it was noticed and recognized only twice. It is a colony alga, the cells of which are embedded in a colorless, relatively soft mucilaginous mass, characterized by amorphous or more or less distinctly marked structure resembling that in Gloeocystis (Fig. 1). This green alga forms colonies of various sizes. Discovered were large aggregates consisting of numerous smaller one-, two-, and four-cell conglomerations surrounded by their own envelo- 

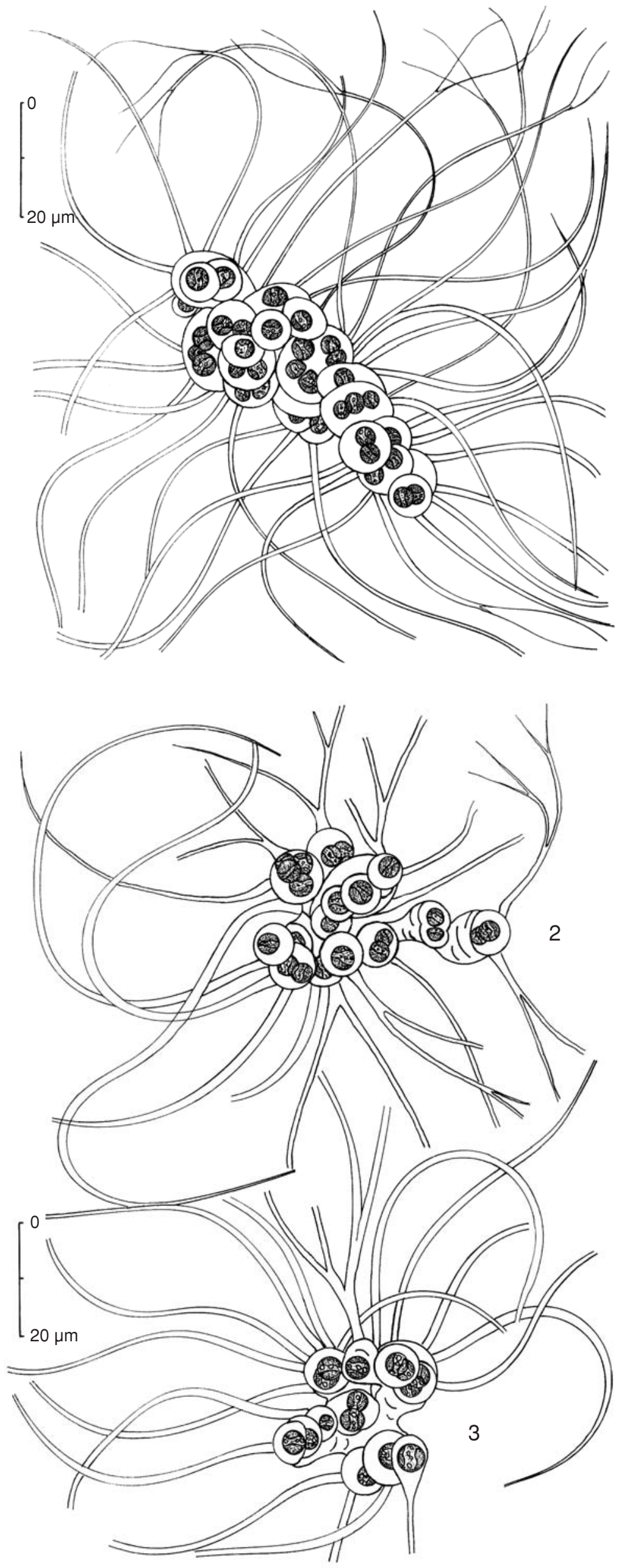

Fig. 1. Chlorodiscus nutans Peter. \& Hans. General appearance of colony.

Figs 2, 3. Colonies consisting of mucilaginous stalks with vesicle-like structures at tops enclosing cells. 


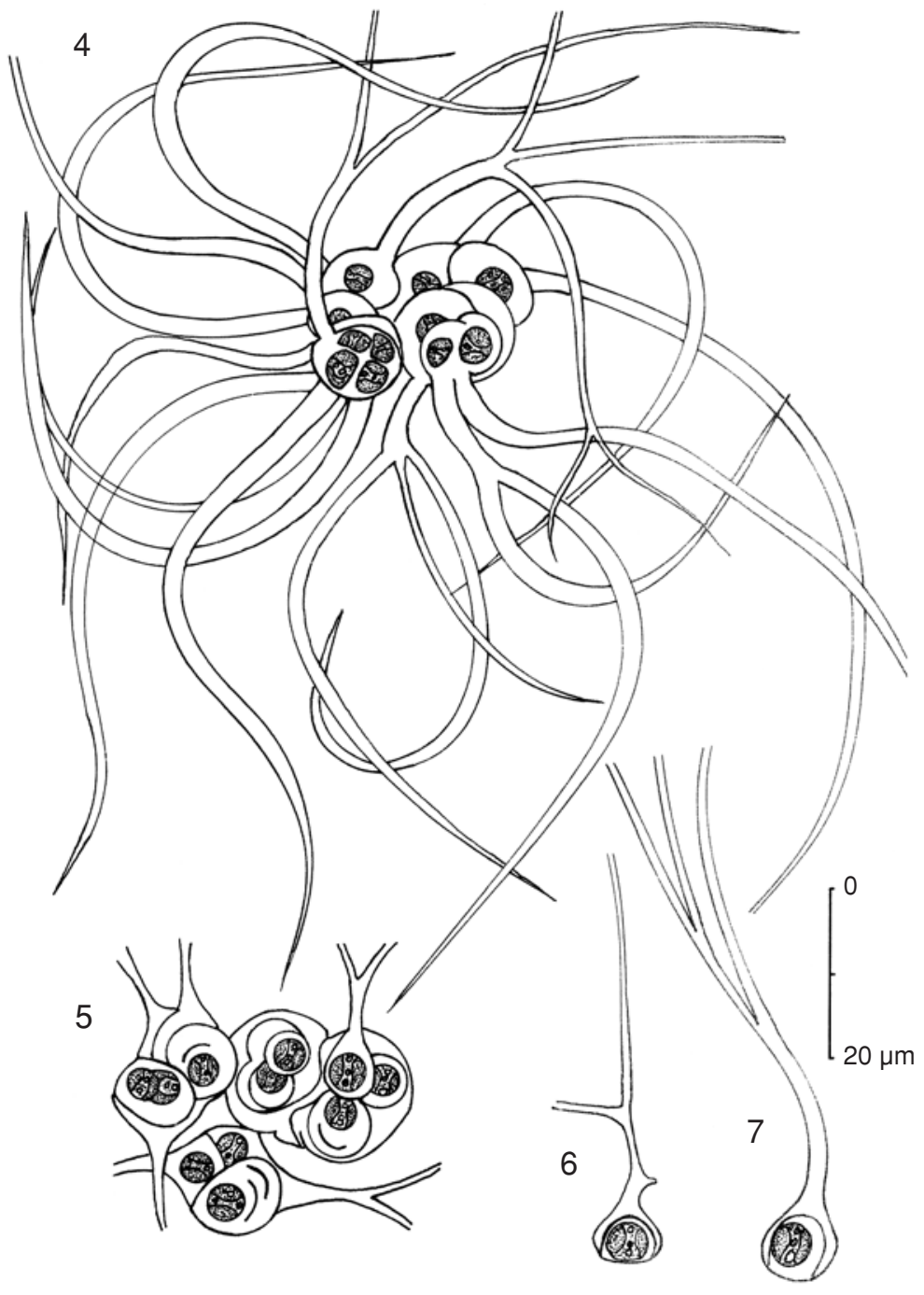

Figs 4, 5. General appearance of colony with visible single, dichotomously or multiple, asymmetrically branched hairs growing out of mucilaginous envelopes enclosing the cells. Figs 6, 7. Single cells enclosed by mucilaginous envelopes, transforming into hairs. pes. Found were also mucilaginous structures consisting of low stalks carrying on their tops single or several cells embedded in mucilaginous envelops (vesicles) (Figs 2, 3). According to the way of structure development within the gelatinous mass, flat or lump colonies were observed. The cells in the latter ones are distributed on various levels. The vesicle-like structures include, in both types of colonies, one or two, or four cells (Figs 4, 5) The mucilaginous structures enclosing the cells turn gradually into long, transparent, elastic and very soft hairs (Figs 6, 7). From each vesicle a single, non-branched, or dichotomously, or multiple asymmetrical branching hair stands out (Fig. 2, Figs 5-7). The transparent hairs are hardly visible without staining with water fuchsin or gentisin. The breadth of hairs at their basis is very variable. The inside of hair is probably hollow (empty). The cells are spherical or slightly oval. Cell walls are delicate, very poorly stainable with mixture of chlorine-zinc-iodine. The protoplast includes one, mostly two disc-like parietal chromatophores. Pirenoids are lacking. In cytoplasm oil drops are visible. After treatment with $\mathrm{Cl}_{2}+\mathrm{Zn}+\mathrm{J}_{2}$ small granulations, probably starch drops, become visible. In the "Brzeźnik" peat bog asexual reproduction by cell division was recorded, however, no production of spores or zoospores was noticed. Cell diameter from 3.0 to $6.0 \mu \mathrm{m}$. The diameter of colony together with sheets including four cells was 10 to $16 \mu \mathrm{m}$, six cells
$20 \mu \mathrm{m}$. Also multicellular colonies of diameter up to 200 $\mu \mathrm{m}$ were observed. Thickness of hairs at base was from 1.0 to $4.5 \mu \mathrm{m}$, length from 1000 to $140 \mu \mathrm{m}$.

Stand: mineromesotrophic peat bog "Brzeźnik" near Bolesławiec, Lower Silesia.

Habitat: ditch with shallow and slow-floating water overgrown by mosses and sedge.

\section{DISCUSSION}

The green alga Chlorodiscus natans discovered by Petersen and Hansen, formed on the water surface mucilaginous colonies variable in size, most frequently in shape of flat, not regular clods or discs slightly convex at one side. The mucilaginous substances, in which cells were embedded, showed a uniform structure. From the mucilaginous envelopes including the cells, numerous transparent, elastic hairs were growing out, which were suspended in the surfacewater layers or were submerged in deep water.

However, the colonies of that green alga found in the peat bog "Brzeźnik", differ in their distinct similar to Gleocystis, or by presence of stalk-like forms building the multidimensional gelatinous clods, but the latter forms were rarely found. The observed colonies floated in the water or were settled in the bottom between plants. The remaining featu- 
res, particularly the kind of hair development and the internal structure of cells, as well as the overall features of the described green alga, are similar to specimens described by Petersen and Hansen.

The systematic position of the discussed taxon is not fixed. This undoubtedly interesting and very characteristic alga has so far not been observed and notified in any of the recent systematic elaborations and keys dedicated to green algae.

Petersen and Hansen, the explorers of this species, suggest its affiliation to Palmellaceae (sensu Fritsch 1965).

According to the Chlorophyceae system accepted by Bourrelli (1966), Starmach (1972), Komárek and Fott (1983), Lee (1999), and Graham and Wilcox (2000), the genus Chlorodiscus could be included among the family of Dicranochaetaceae or among the group of algae closely related with the family. Whereas, according to the system of green algae proposed by Ettl and Gärtner (1988), that alga should be placed in the order of Gloeodendrales (sensu Ettl and Gärtner 1988), family Chaetopeltidiaceae (sensu G.S. West 1904, after Ettl and Gärtner 1988). The hitherto knowledge on this green alga does not allow for its sure classification. The final explanation of its systematic position will be possible not before learning new details of its development, reproduction and its sub microscopic structure of cells and hairs.

\section{LITERATURE CITED}

BOURRELLY P. 1966. Les Algues d' eau douce. I. Les Algues vertes. Eds. Boubée and Cie, Paris.

ETTL H., GÄRTNER G. 1988. Chlorophyta II (Tetrasporales, Chlorococcales, Gloeodendrales). Süsswasserflora von Mitteleuropa, Bd. 10: 1-435. VEB Gustaw Fischer Verlag, Jena.

FRITSCH F.E. 1965. The structure and reproduction of the algae. I. Cambridge Univ. Press.

LEE R.E. 1999. Phycology. Cambridge Univ. Press. Third edition, pp. 171-282.

GRAHAM L.E., WILCOX L.W. 2000. Algae. Prentice-Hall, Inc., Upper Saddle River, pp. 397-543.

MATUŁA J. 1995. Warunki troficzne glonów torfowiskowych na obszarze Dolnego Śląska. Z. Nauk. AR Wrocław 265. Ser. Rozprawy 135: 1-132. (in Polish with English summary).

KOMÁREK J., FOTT B. 1983. Chlorophyceae, Chlorococcales. Die Binnengewässer 16. Das Phytoplankton des Süsswassers 7 (1): 1-1044. Schweizerbart'sche Verlagsbuchhandlung, Stuttgart.

O'KELLY C.J., WATANABE S., FLOYD G.L. 1994. Ultrastructure and phylogenetic relationsships of Chaetopeltidiales ord. nov. (Chlorophyyta, Chlorophyceae) J. Phycol. 30: 118-128.

PETERSEN J.B., HANSEN B. 1960. On some meuston organisms. II Bot. Tidsskr. 56 (3): 197-234. 